\title{
KONSEP TA'WIL USHULIYYIN DAN RELEVANSINYA DENGAN PEMBAHARUAN HUKUM ISLAM
}

\author{
Syahrial Dedi \\ Fakultas Syari'ah IAIN Curup \\ Jl. Dr. AK Gani No. 01 Curup Bengkulu \\ e-mail: dedisyahrial@yahoo.co.id
}

\begin{abstract}
The experts of the Islamic law methodology (Ushuliyyin) have inherited the ta'wil method; a method of discovering the esoteric meaning in the textual disclosure. The application of ta'wil method must be exactly based on predetermined rules of play. The mistake of understanding a method will have negative impact toward the law product. This phenomena was worried about by the ushuliyyin very much. This research is a library study with content analysis method. This study concludes that ta'wil according to ushuliyyin that is, the abrogation of a pronouncement of the meaning of zhabir to another meaning which is not quickly captured, because there is a proposition that the meaning is meant by the pronouncement. Evidence of ta'wil in the form of nash, qiyas, luhgawiyyah, 'aqliyyah, and' adad ('urf), and the argument disputed is the wisdom of al-tasyri' (maqashid al-syari'ah) which is practiced only by ulama ushul al-Hanafiyyah. Ta'wil covers the furu' problems. Ushuliyyin finds some form of ta'wil, among which specializes in general pronouncing (takhshish al'am), limiting the mutlaq (taqyyid al-mutlaq), transfer the utterance from the essential meaning to the majazi, or from the obligatory meaning of the sunnah. Generally the ta'wil method is still considered relevant to the renewal of Islamic law.
\end{abstract}

Kata kunci: ta'wil, ushuliyyin, dalil, lafaz, z̧hahir, Hukum Islam.

\section{PENDAHULUAN}

P emahaman akan kehendak syari' tergantung sepenuhnya kepada pemahaman seorang mujtahid terhadap ayat-ayat dan hadits hukum dalam alQur'an dan sunnah. Usaha pemahaman, penggalian dan perumusan hukum dari kedua nash tersebut di kalangan ulama ushul disebut istinbath. Para pakar metodologi hukum Islam (ushuliyyin), telah mewariskan serangkaian metode untuk memahami kehendak syari' tersebut. Satu di antara metode itu adalah ta'wil, sebuah metode untuk menemukan makna esoteric (batin) dalam pengungkapan teks.

Pada prinsipnya para ushuliyyin sepakat mengatakan adanya penggunaan ta'wil, jika memenuhi pesyaratan yang ada, $t a^{\prime} w i l$ ini disebut dengan istilah $t a^{\prime} w i l$ maqbul, yaitu ta'wil yang tidak jauh beranjak dari arti zahirnya, sehingga dengan petunjuk yang sederhana dapat dipahami maksudnya. Namun jika ta'wil tersebut hanya didasarkan kepada dorongan hawa nafsu dan tidak terpenuhi syarat-syarat yang ditentukan, akibatnya pengalihan makna lahir suatu lafaz yang begitu jauh, tidak dapat diketahui dengan dalil yang sederhana. Maka ta'wil ba'id 
seperti ini ditolak atau diistilahkan dengan ta'wil ghair al-maqbul.

Penelitian dan pengkajian metode ta'wil sebagai salah satu metode istinbath hukum sangat diperlukan, karena hukum biasanya menuntut pemahaman, bukan saja dengan maksud teksnya yang terbaca, tetapi juga dengan makna-makna yang terkandung di dalamnya, termasuk petunjuk dan informasi yang bersifat tidak langsung dari sebuah teks hukum. Di samping itu, pengkajian metode istinbath hukum yang relevan dengan pembaharuan hukum Islam dewasa ini dirasakan sangat perlu dalam rangka menghasilkan produk-produk hukum yang sesuai dengan perkembangan masyarakat.

Pengaplikasian metode $t a^{\prime} w i l$ warisan ushuliyyin, mesti dilakukan secara tepat sesuai aturan main yang telah ditentukan. Kekeliruan dalam memahami sebuah metode, berakibat fatal terhadap prodak hukum yang dihasilkan. Hal inilah yang sangat dikhawatirkan para ushuliyyin. Dikarenakan hal itu, penelitian ini bermaksud mengkaji secara utuh dan komprehensif bagaimana konsep ta'wil ushuliyyin tersebut, serta bagaimana menerapkannya, sehingga $t a^{\prime}$ wil sebagai salah satu metode istinbath hukum relevan atau tidak dengan pembaharuan hukum Islam di Indonesia. Untuk menjawab persoalan tersebut dilakukan kajian kepustakaan (library reseach) dengan metode content analysis (penalaran isi).

\section{KONSEP TA'WIL USHULIYIN}

$\mathrm{Ta}^{\prime}$ wil secara literal, berasal dari kata

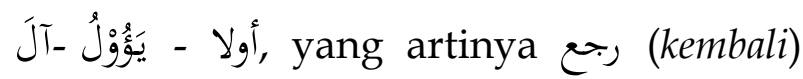
(Ibn Manzur, t.th: 32), maka ungkapan ayat 7 surat Ali Imran “....ابتغاء تأويله"... "

berarti “ما يؤول إليه (sesuatu yang dikembalikan padanya) (Al-Amidi, 2003: 65).

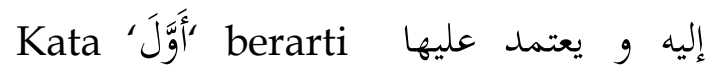
الرجوع (kembali dan bersandar kepadanya) (Al-Raghib al-Isfahani, t.th: 40), juga memberi pengertian unggul dan memiliki pengikut. Bentuk isim makan dan zaman (المرئل/موئلا) juga berarti (tempat kembali) (Ibn Taimiyah, t.th: 30), seperti dalam surat al-Kahfi ayat 58. Ta'wil juga bermakna العاقبة (akibat atau pahala) (Ibn Faris, 1979: 162).

Imam al-Syafi'i (w. 204 H.), ketika menjelaskan ta'wil mengatakan bahwa suatu perkataan atau kalimat terkadang mengandung maksud lain yang tersembunyi dari permukaan, oleh karena itu perlu dijelaskan maksud tersebut. Dengan kata lain, ta'wil merupakan maksud atau makna lain dari perkataan. Hal ini dapat dipahami dari ungkapannya berikut:

الكلام قد يحمل في غير مقصوده ويفصل في مقصوده

(Al-Zarkasyi: 2006: 443) .

Makna lain yang dimaksud Imam alSyafi'i, adalah makna bathin bukan makna zhahir yang dikandung lafaz, sebagaimana katanya:

$$
\text { الصنف الذي يدل لفظه على باطنه دون ظاهره }
$$

(Al-Syafi'i, t.th: 64).

Definisi $t a^{\prime} w i l$ yang populer di kalangan ushuliyin dikemukan oleh Ibn Hajib (w. 646 H.), yaitu:

$$
\text { حمل الظاهر على المحتمل المرجوح }
$$

(Abu Bakr bin 'Ali, t.th: 416). 
Membawa lafaz kepada sesuatu yang tidak ditunjukkannya secara zhahir. Maksudnya, jika ada beberapa kemungkinan makna dalam satu lafaz, maka yang diambil adalah makna yang tersembunyi, bukan makna yang langsung bisa ditangkap dari lafaz tersebut (zhahir) karena ada dalil yang mendukung. Definisi yang sama juga dikemukakan oleh Taj ad-Din Ibn al-Subki (w. 771 H.), tetapi dia menambahkan bahwa bila pengalihan makna tersebut didukung oleh dalil, maka itulah ta'wil yang shahih, namun bila berlandaskan pada anggapan belaka, maka ta'wil itu fasid, atau tanpa landasan sama sekali, maka yang demikian itu adalah mainmain, bukan $t a^{\prime}$ wil. (Al-Subki, 2003: 54).

Definisi-definisi $t a^{\prime} w i l$ di atas, walaupun agak berbeda namun punya kesamaan yang dapat diambil pemahaman bahwa ta'wil merupakan pengalihan lafaz dari makna zhahir kepada makna yang dimaksud (esoteris), karena ada dalil yang menunjukkan bahwa makna itulah yang dimaksud oleh lafaz tersebut. Kesimpulan ini sejalan dengan kesimpulan Adib Shalih tentang pengertian $t a^{\prime}$ wil menurut ulama ushul alfigh yaitu, pemalingan suatu lafaz dari maknanya yang zhahir kepada makna lain yang tidak cepat ditangkap, karena ada dalil yang menunjukkan bahwa makna itulah yang dimaksud oleh lafaz tersebut. (Al-Bannani, 1982: 53).

Dari beragam definisi di atas, terlihat bahwa ranah yang dimasuki $t a^{\prime}$ wil adalah lafaz azh-zhahir karena menunjukkan makna secara zhanni (dugaan kuat), namun masih terbuka terhadap makna lain tetapi hanya dugaan lemah (AlGhazali, 2008: 88).
Pada intinya, tidak boleh meninggalkan makna zhahir lafaz yang telah jelas dengan sendirinya kepada makna lain, kecuali berdasarkan dalil. Jadi, lafaz muawwal dapat menjadi lebih kuat karena dalil. Makna muawwal adalah kemungkinan yang dikuatkan oleh dalil, sehingga menjadi lebih kuat dibanding makna yang ditunjukkan oleh zhahir (AlBanani, 1982: 53). Jadi, ta'wil tanpa berlandaskan dalil atau berlandaskan dalil tetapi lemah atau hanya seimbang (tidak kuat) adalah $t a^{\prime}$ wil yang keliru.

Selain al-zahir, termasuk juga lafaz mujmal jika belum diperjelas (tafsir). Seperti hukum mengusap kepala yang kadarnya masih mujmal, meskipun maknanya jelas, tetapi hal ini membuka ruang untuk ta'wil dalam hal kadarnya. Oleh karena itulah para ulama berbeda pendapat tentang

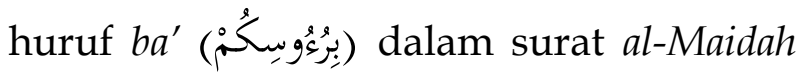
ayat 6 ketika menjelaskan hukum mengusap kepala. Jika nash ayat yang mujmal ini diperjelas (tafsir) niscaya tidak akan ada ta'wil di dalamnya.

Ta'wil tidak berlaku pada nash-nash qath'i, muhkam dan mufassar yang hanya memiliki satu makna dan makna yang dimaksud oleh syari'ah sudah jelas (Zaidan, 1976: 341). Inilah yang dimaksud dengan kaidah umum:

$$
\text { لا مساغ لإجتهاد في مورد النص }
$$

(Tawilah, t.th: 256)

Tidak ada ijtihad beserta nash (alQur'an dan sunnah) (Abu Zainah, 2010: 32), seperti bagian-bagian dalam warisan dan hukuman (had) yang disebutkan dalam nash-nash syar'i terhadap pelaku perbuatan dosa-dosa besar. 
Ranah garapan ta'wil ada dua; pertama, masalah-masalah furu' (nash-nash yang bersinggungan dengan hukumhukum syari'ah). Kedua, masalah-masalah ushul (nash-nash yang terkonsentrasi kepada masalah aqidah, semisal nash yang menceritakan tentang sifat-sifat Allah Azza wa Jalla memiliki tangan, wajah, dan sebagainya. Selain itu, termasuk juga huruf muqaththa'ah di permulaan suratsurat. (Al-Zarkasyi, 2006: 439. AlSyawkani, 2000: 756). Persoalan aqidah inilah garapan ulama tashawwuf dan teologi, sementara persoalan furu' menjadi kajian intens ulama usul al-figh.

Para ulama ushul merupakan kelompok yang paling mendalami kajian ayat-ayat al-Qur'an untuk kepentingan istinbat al-ahkam. Dari pendalaman kajian tersebut, mereka menemukan beberapa bentuk ta'wil, di antaranya mengkhususkan lafaz yang umum (takhshish al-'am), membatasi lafaz yang mutlaq (taqyyid al-mutlaq), mengalihkan lafaz dari maknanya yang hakiki kepada yang majazi, atau dari maknanya yang mengandung wajib menjadi makna yang sunnah (Al-Zuhaili, 1986: 314).

Contoh ta'wil takhshish al-umum adalah firman Allah SWT dalam surat al-Baqarah: 228, yang menerangkan bahwa wanita yang ditalaq oleh suaminya harus menjalani iddah (masa tunggu) selama tiga kali masa haid atau masa suci (tsalatsah quru'). Ayat 228 surat al-Baqarah. Ayat tersebut berlaku umum, baik isteri yang sudah digauli maupun belum, haid, monopouse, atau dalam kondisi hamil. Kemudian ayat ini ditakhshish dengan ayat 49 surat al-Ahzab yang menerangkan bahwa wanita yang belum digauli tidak memiliki iddah, selengkapnya berbunyi:

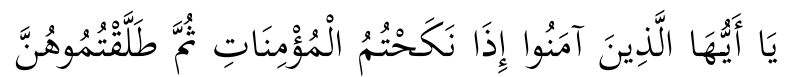

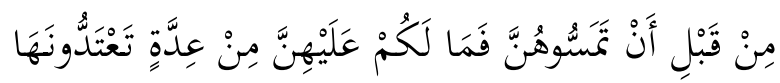

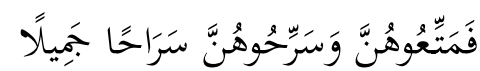

Hai orang-orang yang beriman, apabila kamu menikahi perempuan- perempuan yang beriman. Kemudian kamu ceraikan mereka sebelum kamu mencampurinya. Maka sekali-sekali tidak wajib atas mereka 'id\}d\}ah bagimu yang kamu minta menyempurnakannya. Maka berilah mereka mut'ah dan lepaskanlah mereka itu dengan cara yang sebaik-baiknya. (Q.S. Al-Ahzab [33]: 49).

Mengalihkan lafaz dari maknanya yang muthlaq kepada yang terbatas (muqayyad), dalam bahasa ushul al-figh disebut taqyyid al-muthlaq (المطلق تقييد). Terlihat dalam ayat 3 surat al-Maidah berbunyi:

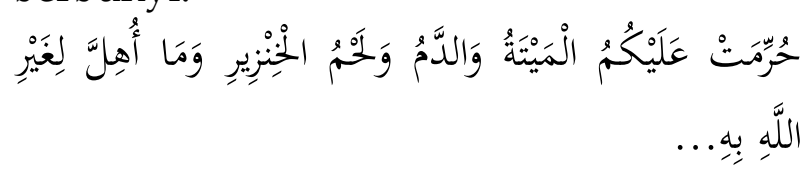

Diharamkan bagimu (memakan) bangkai, darah, daging babi, (daging hewan) yang disembelih atas nama selain Allah,... (Q.S. Al-Maidah [5]: 3).

Keharaman darah secara muthlaq dalam ayat ini kemudian ditaqyyid dengan kata 'mengalir' (masfuhan) dalam ayat 145 surat al-An'am, sehingga yang diharamkan adalah darah yang mengalir, secara tegas dikatakan:

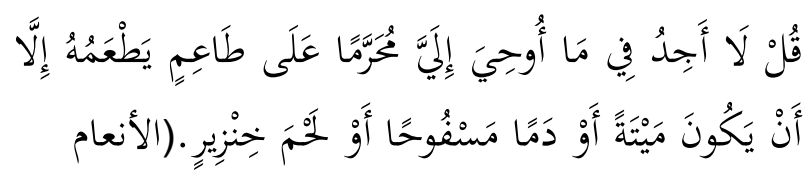

Katakanlah: "Tiadalah aku peroleh dalam wahyu yang diwahyukan kepadaku, sesuatu 
yang diharamkan bagi orang yang hendak memakannya, kecuali kalau makanan itu bangkai, atau darah yang mengalir atau daging babi... (Q.S. Al-An'am [6]: 145).

Mengalihkan lafaz dari maknanya yang hakiki kepada yang majazi. Seperti pada firman Allah SWT dalam surat alNisa' ayat 2 yang menerangkan perintah menyerahkan harta-harta milik anak yatim, yaitu anak yang ditinggal mati oleh orang tuanya sebelum mereka baligh. Tegasnya berbunyi:

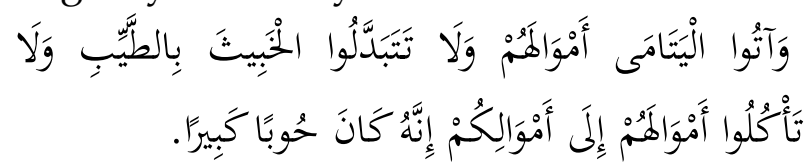

Dan berikanlah kepada anak-anak yatim (yang sudah baligh) harta mereka, jangan kamu menukar yang baik dengan yang buruk dan jangan kamu makan harta mereka bersama hartamu. Sesungguhnya tindakan-tindakan (menukar dan memakan) itu, adalah dosa yang besar. (Q.S. An-Nisa [4]: 2).

Ayat ini bertentangan dengan ayat 6 surat al-Nisa' yang menerangkan untuk menyerahkan harta-harta milik anak yatim pada saat mereka telah baligh dan dewasa. Ayat tersebut berbunyi:

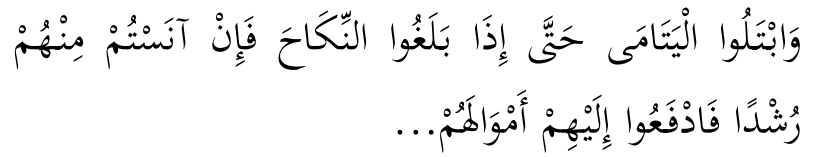

Dan ujilah anak yatim itu sampai mereka cukup umur untuk kawin. Kemudian jika menurut pendapatmu mereka telah cerdas (pandai memelihara harta), maka serahkanlah kepada mereka hartahartanya... (Q.S. An-Nisa[4]: 6).

Ayat kedua ini, dapat dipahami bahwa yang dimaksud dengan lafaz yatim pada ayat yang pertama bukan makna hakiki (anak yang ditinggal mati oleh orang tuanya sebelum mereka baligh), tetapi makna majazi yaitu ketika mereka telah baligh dan dewasa.

Mengalihkan lafaz dari maknanya yang mengandung wajib menjadi makna yang sunnah, seperti perintah untuk mencatat hutang piutang dalam surat alBaqarah: 282:

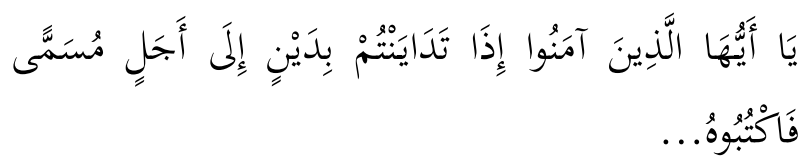

Hai orang-orang yang beriman, apabila kamu bermu'amalah tidak secara tunai untuk waktu yang ditentukan, hendaklah kamu menuliskannya... (Q.S. Al-Baqarah [2]: 282).

Kewajiban mencatat hutang piutang ini kemudian dialihkan menjadi sunnah oleh ayat 283 surat al-Baqarah:

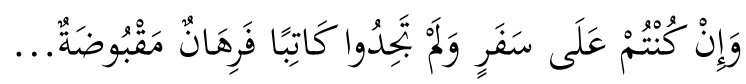

ika kamu dalam perjalanan (dan bermu'amalah tidak secara tunai) sedang kamu tidak memperoleh seorang penulis, maka hendaklah ada barang tanggungan yang dipegang (oleh yang berpiutang)... (Q.S. Al-Baqarah [2]: 283).

Adapun syarat-syarat melakukan ta'wil sebagai berikut:

1. Adanya sebab yang menghendaki $t a^{\prime} w i l$ (Thawilah, t.th: 262), seperti pertentangan antara dua dalil yang sulit untuk diamalkan kecuali dengan jalan ta'wil. Jika salah satunya shahih atau kuat, dan lainnya lemah, maka yang diambil adalah yang shahih atau yang kuat.

2. Ta'wil tidak boleh menggugurkan nash syar'i lainnya (Abu Munir, 2011, 328. 
Zaidan, 1976: 341), karena ta'wil merupakan salah satu metode ijtihad yang bersifat zhanni sedangkan nash yang bersifat zhanni tidak bisa mengalahkan nash yang bersifat qath'i.

3. Lafaz yang ingin dita'wil adalah lafaz yang pada asal menerima dan bisa dita'wil (Abu Munir, 2011: 328. AlSyathibi, 1979: 330). Misalkan, lafaznya adalah lafaz umum yang dapat dikhususkan (ditakhshish), atau lafaz muthlaq yang dapat diberi batasan (taqyid), atau lafaz bermakna hakiki yang dapat diartikan secara makna metaforis (majazi), dan sebagainya. Maka, jika $t a$ 'wil dilakukan pada nash khusus (bukan nash umum), tidak diterima (Al-Zuhaili, 1986: 314).

4. Ta'wil harus berdasarkan pada dalil yang shahih dan dalil makna batin harus lebih kuat daripada makna zhahir (AlSyathibi, 1979: 331. Al-Syawkani, 2000: 759).

5. Ta'wil yang dihasilkan mesti selaras dengan makna bahasa Arab, makna syar'i, atau makna 'urf (kebiasaan orang Arab) (Al-Syawkani, 2000: 759). Ada beberapa istilah yang digunakan oleh ulama ushul untuk makna syari', yaitu عرف إصطلاح الشرع (Thawilah, t.th: 262), (Zakariya al-Barusi, t.th: 389. AlZuhaili, 1986: 315), عادة صاحب الشرع (A1Syawkani, 2000: 759. Al-Zarkhasyi, 2006: 443). Ulama yang memakai istilah, عرف dan عرف, memasukannya kepada perluasan dari dalil 'urf. Sementara ulama lainnya menganggap makna yang diletakkan syari'ah, merupakan kelompok dalil tersendiri. Pada intinya, pengistilahan tersebut memiliki patokan makna yang sama, yaitu perspektif syari'ah, namun berbeda dalam penempatan.

6. Jika ta'wil dengan qiyas maka, hendaknya menggunakan qiyas al-jaliy (Al-Syawkani, 2000: 759).

7. Para Pelaku ta'wil, haruslah berkualifikasi mujtahid yang memiliki bekal ilmu-ilmu bahasa Arab dan ilmuilmu syar'i (Al-Amidi, 2003: 67. AlZuhaili, 1986: 315). Orang yang tidak memiliki kualifikasi tersebut dilarang melakukannya karena akan dikhawatirkan terjatuh pada perbuatan yang dilarang.

Sebagaimana yang telah diuraikan di atas, bahwa ta'wil harus berdasarkan dengan dalil (qarinah) yang kuat, agar tidak dianggap $t a^{\prime}$ wil batil dan mengikuti hawa nafsu (Al-Subki, 2003: 54). Ta'wil harus berdasarkan pada dalil yang sahih dan dalil makna batin harus lebih kuat dari pada makna zhahir (Al-Syatibi, 1997: 331). Sedangkan bentuk dalil yang dipergunakan untuk melakukan ta'wil adalah (1) nash (ayat dan hadits), (2) qiyas, dan (3) dalil berupa qarinah.

Qarinah (القرينة) artinya adalah petunjuk yang memalingkan dari makna zhahir kepada makna yang lemah. Dalil yang berupa qarinah ini ada dua bentuk; pertama, qarinah munfashilah (قرينة منفصلة), yaitu indikasi dari luar lafaz umpama, seorang tentara Muslim jika datang ke tempat orang musyrik, mereka mengatakan bahwa tentara Muslim itu aman. Tetapi dibantah oleh tentara Muslim bahwa itu adalah tipu muslihat saja. Secara ta'wil dibenarkanlah perkataan orang musyrik tersebut. Menurut zhahir perkataan orang Muslim 
itu memang lebih kuat lantaran sifat keadilan dan keislamannya (لعدالتهوالإسلامه), sementara perkataan orang musyrik lemah disebabkan sifat kafirnya, dan secara kondisi memungkinkan menangkap tentara Muslim. Namun sifat 'adalah dan kafir itu berada di luar pembicaraan (lafaz) (Al-Namlah, 1999: 1209).

Kedua, qarinah muttashilah ( قرينة متصلة), yaitu indikator yang terdapat di dalam lafaz, contoh larangan menarik kembali hibah yang telah dilakukan. Secara zhahir hadits mengatakan bahwa العائد في هبته كالكلب يقيء ثم يعود في قيئه yang menarik kembali pemberiannya seperti anjing yang muntah kemudian menjilatnya). Menurut makna zhahir tidak ada larangan menarik hibah karena anjing tidak haram menjilat muntahnya. Tetapi ada qarinah yang berhubungan dengan nash tersebut ليس لنا ' yaitu, awal hadits yang berbunyi السوء (tiada bagi kita seumpama kejahatan). Qarinah ini merupakan dalil yang kuat untuk melarang mengambil kembali hibah yang telah diberikan (Al-Namlah, 1999: 1209. Abu Munir, 2011: 329).

Ulama ushul membagi ta'wil pada tiga bentuk. (Al-Syawkani, 2000: 759.)

a. Ta'wil qarib (تأويل قريب), yaitu ( فيترجح بأدنى (مرجح ta'wil yang tidak jauh beranjak dari arti zhahirnya, sehingga dengan petunjuk yang sederhana dapat dipahami maksudnya, contoh:

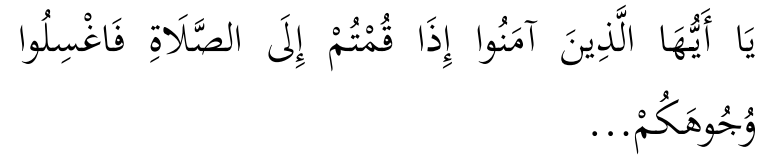

Hai orang-orang yang beriman, apabila kamu hendak mengerjakan shalat, maka basuhlah mukamu... (Q.S. Al-Maidah [5]: 6).

"العزم على أداء Ayat ini dita'wil dengan " (keinginan untuk mengerjakan shalat). Bahwa syari'at tidak menuntut melakukan wuduk dari mukallaf sesudah mengerjakan shalat karena wuduk merupakan salah satu syarat sah shalat dan syarat mesti terpenuhi sebelum yang disyaratkan.

b. Ta'wil ba'id (تأويل بعيد), yaitu pengalihan dari makna lahir suatu lafaz yang sebegitu jauhnya, sehingga tidak dapat diketahui dengan dalil yang sederhana, dia membutuhkan dalil yang lebih kuat (فلا يترجح إلا بمرجح قوي). Mengenai $t a^{\prime}$ wil kepada makna yang jauh dari makna zhahirnya, terdapat perbedaan pendapat di kalangan ulama ushul al-Syafi'iyyah dan ushul alHanafiyyah. Karena perbedaan pendapat dalam persyaratan di atas, maka terdapat perbedaan pendapat di antara kedua kelompok ulama itu dalam beberapa masalah furu'.

c. Muta'zar (تأويل متعذر), yaitu ta'wil yang terlarang untuk dilakukan karena tidak ada dalil yang menopangnya ( لايرتجح بما (ليس بقوي (2).

Berdasarkan klasifikasi di atas, dengan melihat pada lafaz yang dita'wil itu, maka terbagilah ta'wil pada ( التأويل -diterima-dan (المقبول)ditolak. Bila terdapat dalil kuat yang akan 
memberi petunjuk kepada maknanya, maka $t^{\prime}$ 'wil termasuk kepada yang maqbul. Tetapi jika pada lafaz itu tidak terdapat dalil kuat yang menjelaskannya dan tidak dapat diketahui dengan dalil sederhana, maka ta'wil ini termasuk gahir al-maqbul.

Ada juga yang membagi $t a^{\prime}$ wil itu pada dua kategori, yaitu ta'wil qarib dan ta'wil fasid, dan kemudian berujung pada ta'wil shahih dan tidak shahih. Klasifikasi ini dengan memperhatikan dalil yang dipergunakan. Jika dalil yang dipergunakan kuat, dinamakan ta'wil shahih, namun jika dalilnya lemah dinamakan fasid.

\section{RELEVANSI METODE TA'WIL DENGAN PEMBAHARUAN HUKUM ISLAM}

Untuk melihat relevansi metode ta'wil dengan pembaharuan hukum Islam di Indonesia perlu ditampilkan contoh kasus. Kemudian kasus tersebut akan dianalisa dengan menggunakan metode ta'wil, dari sinilah terlihat relevansi metode $t a^{\prime} w i l$ yang diwariskan ulama $u s u l$ al-figh. Contoh yang diangkat adalah Pembatasan usia Perkawinan.

Batasan usia minimal calon pengantin memang tidak dibicarakan dalam kitab-kitab figh. Bahkan dijumpai dalam kitab-kitab figh kebolehan mengawinkan antara laki-laki dan perempuan yang masih kecil (Ibn alHumam: 2003: 264). Hal ini juga terlihat dari kewenangan wali mujbir mengawinkan anak-anak yang masih kecil. Bahkan ditemukan prediksi kasus; jika seorang laki-laki menikahi anak perempuan yang masih bayi, kemudian bayi tersebut menyusu kepada ibu mertuanya, maka si isteri tersebut menjadi haram hukumnya (Al-Jaziri, t.th: 94). Hal ini berarti kebolehan melangsungkan pernikahan selagi pengantin perempuan masih bayi.

Kebolehan itu, dikarenakan tidak dijumpai ayat al-Qur'an dan hadits yang secara terang dan terarah menyebutkan batas usia minimal pengantin. Dasar pemikiran tidak adanya batas umur pasangan yang akan kawin itu kiranya sesuai dengan pandangan umat ketika itu tentang hakikat perkawinan. Mereka memandang perkawinan tidak dilihat dari segi hubungan kelamin, tetapi dari segi pengaruhnya dalam menciptakan hubungan mu'asyarah. Nabi SAW mengawini 'Aisyah anak Abu Bakr dalam usia 6 tahun di antaranya ditujukan untuk kebebasan Abu Bakr memasuki rumah tangga Nabi SAW, karena di situ terdapat anaknya sendiri. Namun di zaman sekarang, perkawinan itu lebih ditekankan kapada tujuan hubungan kelamin. Dengan demikian, tidak adanya batas umur sebagaimana yang terdapat dalam kitab-kitab figh tidak relevan lagi (Amir, 2009: 66-67).

Al-Qur'an hanya memberikan sinyal yang dapat ditangkap tentang batas umur minimal untuk melangsungkan pernikahan, yaitu surat al-Nisa' ayat 6 selengkapnya berbunyi:

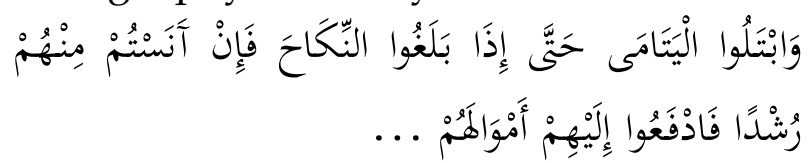

Dan ujilah anak yatim itu sampai mereka cukup umur untuk kawin. Kemudian jika menurut pendapatmu mereka telah cerdas (pandai memelihara harta), maka serahkanlah kepada mereka hartahartanya... (Q.S. An-Nisa [4]: 6).

Ayat ini dapat dipahami bahwa pernikahan itu mempunyai batas usia 
minimal calon pengantin, yaitu baligh. Hal ini diperkuat oleh hadits:

Dari 'Abdullah (bin Mas'ud), dia berkata:

"Telah bersabda Rasulullah SAW untuk kita": Ya pemuda, siapa di antara kamu yang sudah sanggup dalam persiapan kawin, maka hendaklah menikah, pernikahan itu memelihara pandangan dan memelihara kemaluan, namun siapa yang belum mampu dalam persiapan kawin, hendaklah dia berpuasa, sesungguhnya puasa itu adalah obat. (HR: Muslim). (AlMaktabah, Hadits No 1400).

Hadits ini menyebutkan persyaratan untuk melangsungkan pernikahan, yaitu memiliki kemampuan persiapan untuk kawin. Persyaratan tersebut hanya dapat terjadi bagi orang yang sudah baligh. Kata baligh dalam ayat di atas, secara etimologi berarti matang, masak, dewasa, mencapai akil baligh (Munawwir, 1997: 107).

Menurut al-Thabari, ungkapan حتى (jika sudah mengalami mimpi basah) (Al-Thabari, 2001: 404). Hal yang sama juga dikatakan حتى إذا الحلم (Al-Qurthubi, 2010: 24). Pemaknaan ini didukung oleh surat an-Nur ayat 59 berikut:

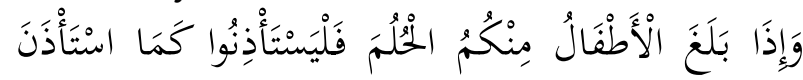

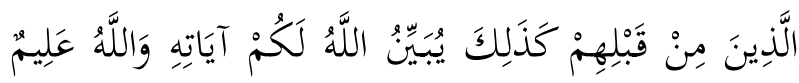

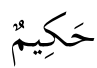

Dan apabila anak-anakmu telah bermimpi (baligh), maka hendaklah mereka meminta izin, seperti orang-orang yang sebelum mereka meminta izin. Demikianlah Allah menjelaskan ayat-ayat-Nya. Dan Allah
Maha mengetahui lagi Maha Bijaksana. (Q.S. An-Nur [24]: 59).

البلوغ dafaz الحلم dalam ayat berarti وحال النكاح. Maksudnya, anak yang telah pernah mengalami mimpi basah, maka sudah dianggap baligh dan siap untuk melakukan pernikahan (Al-Qurthubi, 24). Dengan demikian, kata al-baligh dita'wil dengan al-hulm. Selain itu, kata baligh juga dita'wil dengan kriteria seseorang dianggap sudah baligh.

Seseorang sudah dianggap baligh, jika memenuhi lima persyaratan. Tiga dari persyaratan tersebut, terdapat pada lakilaki dan perempuan, sedangkan dua terkhusus untuk perempuan, yaitu haid dan hamil. Adapun tiga yang lain adalah mimpi, pertumbuhan dan umur (AlQurthubi, 2010: 24) Imam al-Syafi'i, Ibn Hanbal, Ibn Wahhab, Ashbagh, 'Abd alMalik bin al-Majasyun, 'Umar bin 'Abd al'Aziz serta satu kelompok dari ahl alMadinah berpendapat bahwa umur 15 tahun sudah dianggap baligh, bagi orang yang belum bermimpi. Pendapat ini diperkuat oleh hadits Ibn 'Umar yang menceritakan:

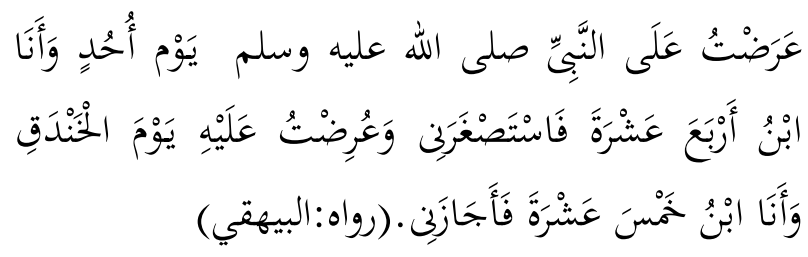

Saya telah mengajukan diri kepada Nabi SAW untuk ikut perang Uhud yang waktu itu saya baru berumur 14 tahun, beliau tidak mengizinkan aku. Dan aku mengajukan diri lagi kepada beliau tatkala perang Khandaq, waktu umurku 15 tahun, dan beliau membolehkan aku (untuk mengikuti). (HR: al-Baihaqi) (AlMaktabah, Hadits No. 262). 
Imam Malik dan Abu Hanifah berpendapat bahwa usia baligh itu adalah 17 tahun. (Al-Qurthubi, 2010: 25). Namun dijelaskan oleh Muhammad, bahwa 17 tahun itu untuk usia anak perempuan (الجارية) yang belum haid, dan 19 tahun untuk usia anak laki-laki (الغلام) yang belum pernah mimpi basah. Abu Hanifah membedakan usia anak laki-laki dengan perempuan. Tetapi menurut versi alHasan, Abu Hanifah menetapkan 18 tahun untuk laki-laki (Al-Thahawi: 1995:5). Sementara menurut Dawud, yang jadi perhitungan baligh adalah al-hulm (mimpi) bukan umur. ( Al-Qurthubi, 2010: 25).

Ciri selanjutnya adalah al-inbat, yaitu ciri fisik yang menujukan kedewasaan (Al-Qurthubi, 2010: 25), seperti suara membesar, dan munculnnya jakut bagi laki-laki, bentuk pinggul yang membesar dan kemunculan buah dada bagi perempuan. Menurut Imam al-Syafi'i, berdasarkan hadits dari 'Uthiyah alQurazi bahwa bulu-halus (bulu remang) yang tumbuh pada tubuh seseorang belum menyebabkan adanya hukum, tatapi yang diperhitungkan adalah bulu yang sudah menjadi rambut. Sedangkan menurut Imam Malik menurut informasi Ibn al-Qasim berdasarkan hadits dari 'Umar bin al-Khaththab, bahwa seseorang dianggap baligh jika memungkinkan berlalunya al-mawasi (pisau cukur) (AlQurthubi, 2010: 25). Maksudnya, rambut tersebut sesudah memungkinkan untuk dicukur.

Dengan demikian, seseorang yang belum baligh tidak dapat dikenakan hukum sesuai dengan bunyi hadits berikut:

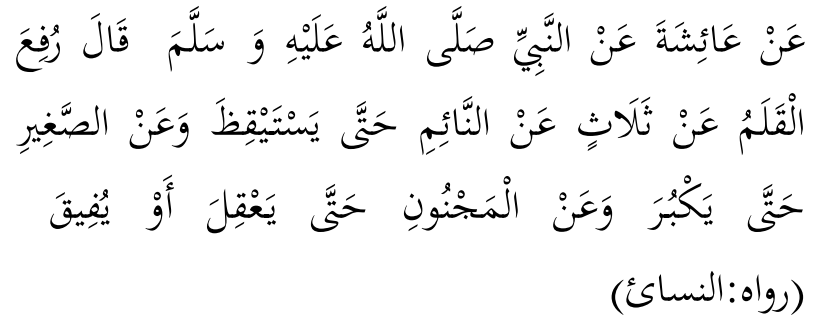

Dari 'Aisyah telah bersabda Nabi SAW: Terangkat pertanggungjawaban seseorang dari tiga hal; orang yang tidur hingga ia bangun, anak-anak hingga ia besar (bermimpi dan mengelurkan air mani) dan orang gila hingga ia sembuh atau wafa. (HR: al-Nasa'i). (Al-Maktabah, Hadits No. 3378).

Menurut isyarat hadits tersebut, kematangan seseorang dilihat pada gejala kematangan seksualitasnya, yaitu keluar mani bagi laki-laki dan menstruasi (haid) bagi perempuan. Dari segi umur, kematangan ini, masing-masing orang berbeda saat datangnya. Indikasi dari kedua hadits di atas, dipahami bahwa batas usia 15 tahun sebagai awal masa kedewasaan bagi anak laki-laki. Karena biasanya pada usia tersebut anak laki-laki telah mengeluarkan air mani melalui mimpinya. Adapun bagi perempuan, 9 (sembilan) tahun untuk daerah seperti Madinah telah dianggap memiliki kedewasaan. Ini didasarkan kepada pengalaman 'Aisyah ketika dinikahi Rasulullah SAW:

'Aisyah menyampaikan: Rasulullah SAW menikah dengan dia ('Aisyah) dalam usia enam tahun, dan beliau memboyongnya ketika ia berusia 9 (sembeilan) tahun, dan beliau wafat pada waktu dia berusia delapan belas tahun. (HR: Muslim). (AlMaktabah, Hadits No. 2550).

Hadits ini dapat dikaitkan dengan perintah Rasulullah SAW kepada kaum muslimin agar mendidik anaknya manjalankan shalat pada saat berusia 


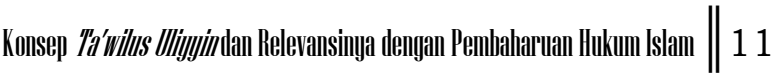

tujuh tahun, dan memukulnya pada usia sepuluh tahun, apabila si anak enggan menjalankan shalat. Di samping itu pemahaman terhadap nash, utamanya yang dilakukan oleh Rasulullah SAW pada saat menikah dengan 'Aisyah, juga perlu dipahami sesuai dengan tuntutan situasi dan kondisi waktu itu. Ini penting, karena tuntutan kemaslahatan yang ada waktu itu dibanding dengan sekarang, jelas sudah berbeda (Rofiq, 1998: 83).

Di Indonesia, Undang-Undang Perkawinan No.1 tahun 1974, pasal 6 ayat 2 memberikan batasan umur minimal calon mempelai adalah 21 tahun, tetapi belum ditetapkan secara tegas bagi siapa umur 21 tahun tersebut. Kemudian pada pasal 7 ayat (1) baru dipastikan rincian batas usia yang diizinkan dalam suatu perkawinan menurut UU yaitu, jika pihak pria sudah mencapai umur 19 (sembilan belas) tahun, dan pihak wanita sudah mencapai umur 16 (enam belas) tahun. (UU No. 1 Tahun 1974: 3). Nampaknya pada pasal 7 ayat (1) ini, terjadi pengurangan, yaitu; untuk laki-laki minimal 19 tahun dan perempuan minimal umur 16 tahun.

Kompilasi Hukum Islam (KHI), dalam pasal 15 ayat 1 , menyebutkan bahwa batas usia minimal melangsungkan perkawinan sama seperti pasal 7 UU No. 1 Tahun 1974, namun dengan tambahan alasan: untuk kemaslahatan keluarga dan rumah tangga, selengkanya berbunyi:

“Untuk kemaslahatan keluarga dan rumah tangga, perkawinan hanya boleh dilakukan calon mempelai yang telah mencapai umur yang ditetapkan dalam pasal 7 Undang-Undang No.1 tahun 1974 yakni calon suami sekurang-kurangnya berumur 19 tahun dan calon isteri sekurangkurangnya berumur 16 tahun". (Direktorat Pembinaan Peradilan Agama Islam Ditjen Pembinaan Kelembagaan Islam Departemen Agama, 2001: 3).

Dengan demikian, kata baligh dalam ayat 6 surat al-Nisa' di atas, untuk konteks perkawinan di Indonesia dita'wil dengan umur 19 tahun bagi laki-laki dan 16 tahun bagi perempuan. Umur 19 tahun bagi lakilaki, berdasarkan hitungan umur tamatan Sekolah Menengah Atas (SMA). Sedangkan umur 16 tahun untuk perempuan merupakan umur tamatan Sekolah Menengah Pertama (SMP). Perhitungan usia tamatan sekolah tersebut sudah menjadi tradisi dalam dunia pendidikan di Indonesia, karena usia wajib belajar itu adalah 7 tahun. Umur laki-laki dilebihkan dari umur perempuan dikarenakan laki-laki menjadi pemimpin dalam rumah tangga. Minimal pimpinan itu tamatan SMA, sama halnya dengan hadits yang menjelaskan umur 'Abdullah bin Umar 15 tahun sewaktu diizinkan ikut perang Khandak dan umur 'Aisyah 9 tahun hidup berumah tangga dengan Nabi SAW. Artinya ada selisih umur antara laki-laki dan perempuan. Penentuan umur laki-laki 19 tahun itu, sama dengan pendapat Abu Hanifah versi Muhammad.

Pembatasan dengan umur tersebut didukung oleh pemahaman ayat dan hadits Rasul SAW. Juga didukung oleh alasan untuk kemaslahatan keluarga dan rumah tangga, agar terwujud keluarga atau rumah tangga yang bahagia dan kekal berdasarkan Ketuhanan Yang Maha 
Esa, sesuai dengan UU Perkawinan No. 1 tahun 1974 (UU No. 1 Tahun 1974: 2).

Selain itu, perkawinan mempunyai hubungan dengan masalah kependudukan. Ternyata batas umur yang rendah bagi seorang wanita untuk kawin, mengakibatkan laju kelahiran lebih tinggi. Berhubung dengan itu, UndangUndang Perkawinan ini menentukan batas umur untuk kawin baik bagi pria maupun wanita. (Penjelasan Umum UU Perkawinan, No. 4 huruf d).

Pertimbangan

problem kependudukan, seperti diungkapkan dalam penjelasan UU Perkawinan, turut mempengaruhi perumusan batas umur calon mempelai tersebut. Ini dimaksudkan untuk menjawab tantangan dan kebutuhan masyarakat, sejalan dengan tujuan hukum Islam itu sendiri. Semua itu merupakan masalah ijtihadiyyah yang diselesaikan dengan ijtihad ulama Indonesia dengan menggunakan metodemetode istishlah, itihsan, dan al-urf serta metode istidlal lainnya dengan tujuan jalb al-mashalih wa dar'al-mafasid (Djatmika, 1991: 254).

Argumen-argumen di atas, menjelaskan bahwa kawin muda mempunyai banyak dampak negatif ketimbang dampak positif. Kawin muda akan membawa kepada kerusakan secara fisik, psikologis dan dampak sosial terhadap pasangan suami isteri. Oleh karena itu, KHI dan Undang-undang lainnya mempersempit dan mengantisipasi terjadinya kawin muda dengan memberikan batasan umur kepada calon suami isteri, agar terhindar dari kebinasaan. Hal ini dilegitimasi oleh al-Qur'an surat al-Baqarah ayat 195:

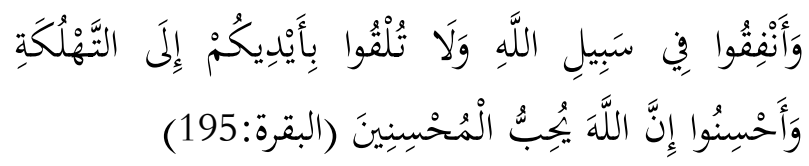

Dan belanjakanlah (harta bendamu) di jalan Allah, dan janganlah kamu menjatuhkan dirimu sendiri ke dalam kebinasaan, dan berbuat baiklah, karena sesungguhnya Allah menyukai orangorang yang berbuat baik. (Q.S. Al-Baqarah [2]: 195).

Masalah penentuan umur dalam UU Perkawinan maupun dalam KHI, sebagai usaha pembaharuan pemikiran figh yang lalu, juga didukung oleh isyarat surat $A n$ Nisa' ayat 9:

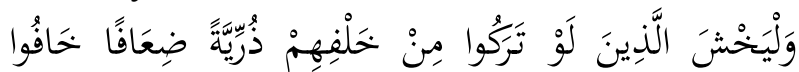

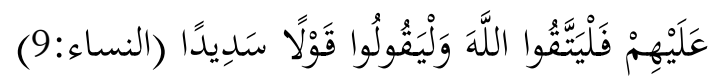

Dan hendaklah takut kepada Allah orangorang yang seandainya meninggalkan dibelakang mereka anak-anak yang lemah, yang mereka khawatir terhadap (kesejahteraan) mereka. Oleh sebab itu hendaklah mereka bertakwa kepada Allah dan hendaklah mereka mengucapkan perkataan yang benar. (Q.S. An-Nisa [4]: 9).

Ayat tersebut memang bersifat umum, tidak secara langsung menunjukkan bahwa perkawinan yang dilakukan oleh pasangan usia muda-di bawah ketentuan yang diatur UU Perkawinan No.1 tahun 1974-akan menghasilkan keturunan yang dikhawatirkan kesejahteraannya. Tetapi berdasarkan pengamatan berbagai pihak, rendahnya usia kawin, lebih banyak menimbulkan hal-hal yang tidak sejalan dengan misi dan tujuan perkawinan, yaitu terwujudnya ketenteraman dalam rumah tangga berdasarkan kasih dan sayang. Tujuan ini tentu akan sulit terwujud, apabila masing-masing mempelai belum 
masak jiwa dan raganya. Kematangan dan integritas pribadi yang stabil akan sangat berpengaruh di dalam menyelesaikan setiap problem yang muncul dalam menghadapi liku-liku dan badai rumah tangga. Banyaknya kasus perceraian cenderung didominasi karena akibat kawin dalam usia muda.

Akses dari kawin muda tersebut dapat dilihat dengan banyaknya masalah yang timbul di tengah masyarakat, antara lain:

a. Menikah dalam usia muda berarti pula hilangnya kesempatan untuk melanjutkan pendidikan. Di satu sisi, tertutupnya akses untuk melanjutkan pendidikan kepada jenjang perguruan tinggi karena disibukkan dengan urusan rumah tangga, beban ekonomi domestik perempuan hamil, melahirkan dan mengurusi anak. Di sisi lain, bagi yang masih di sekolah lanjutan adalah tidak diizinkannya mengikuti pelajaran jika mereka berstatus kawin atau dalam keadaan hamil.

b. Perkawinan yang sangat dini, sebagian besar minim atau sama sekali tidak memiliki pengetahuan tentang hubungan seksual dan kesehatan reproduksi. Ketidaktahuan ini dalam tingkat tertentu akan menyebabkan ketakutan dalam melakukan hubungan seksual. Kemudian, setelah mendapat pengalaman seksual pada umumnya mereka memandang hubungan seksual sebagai kewajiban seorang isteri untuk melayani suami. Terkadang dampak terhadap perempuan adalah aborsi, sebab secara fisik dan mental isteri belum siap untuk hamil (Hasyim (ed), 1999: 143).
Pria yang kawin di bawah umur mempunyai akibat yang sama seperti halnya perempuan. Suami tidak memiliki kesiapan fisik, materi atau yang lebih penting adalah secara psikologi untuk mendayung bahtera rumah tangga yang sangat sarat dengan kesabaran, ketulusan, dan keuletan.

Pembatasan umur seperti yang terdapat dalam KHI dan beberapa Undang-undang lainnya adalah sebagai langkah antisipasi atau pencegahan, agar implikasi negatif dapat dielaminisir dan diminimalisasi dalam rangka menjaga rusaknya eksistensi jiwa, keturunan, dan akal pada tingkat maslahah al-dharuriyah dan al-hajjiyah. Apabila hal ini diabaikan akan berdampak buruk terhadap kedua pasangan suami isteri dan anak-anak secara fisik, psikologi dan sosiologis, sehingga menimbulkan problem sosial. Pada akhirnya akan menjadi penyakit masyarakat dan bahkan dapat mengganggu stabilitas masyarakat dan negara.

Ada kaidah fiqhiyah yang berbunyi: درء المفاسد مقدم dan لاضرر ولاضرار ,الضرر يزال (Al-Syayuti, t.th: 59). Jika dikaitkan dengan kawin muda, memberi pemahaman bahwa bahaya itu harus dihilangkan, dalam artian mencegah kawin muda disebabkan dampak yang membahayakan kepada pasangan suami isteri yang telah diuraikan di atas. Tidak boleh membuat mudharat pada diri sendiri dan tidak pula mudharat untuk orang lain. Kawin muda akan membuat dampak negatif terhadap fisik dan psikologi lakilaki dan perempuan, dan implikasinya akan terpenetrasi kepada dampak sosial masyarakat. Menghindarkan kerusakan 
lebih diprioritaskan daripada meraih keuntungan. Kawin muda memiliki dampak positif, namun dampak negatifnya jaul lebih besar, maka menghindarkan dampak negatif lebih diutamakan dalam agama daripada mengambil dampak positifnya.

Oleh sebab itu, pasal-pasal tersebut dibuat dan dapat ditetapkan dengan pertimbangan demografis, sosiologis, budaya dan agama karena ada kemaslahatan yang ingin dicapai. Agaknya materi Undang-undang tentang pembatasan umur ini lebih bersifat sebagai aturan tambahan karena tidak ada nash yang mengaturnya secara tegas. Aturan ini menyalahi apa yang berlaku dalam kitab-kitab figh mana saja. Namun, jika dianalisa secara lebih mendalam, pembatasan umur tersebut dapat diterima karena baik secara langsung atau tidak, ada ulama yang mengakuinya. Ibn Syubramah dan al-Buti, berpendapat tentang tidak sah (terlarang) mengawinkan perempuan di bawah umur bahkan akad yang dilangsungkan oleh walinya dipandang batal dan tidak berpengaruh. Pendapat ini dilontarkan oleh keduanya karena tidak ada hikmah tasyri' yang ingin dicapai pada perkawinan anak di bawah umur, bahkan mudharat yang terkandung dalam akadnya lebih banyak. Karena mereka (anak kecil belum sampai umur) tersebut merasa terpaksa untuk mengadakan perkawinan (Al-Siba'i, t.th: 58).

KHI dan UU Perkawinan No. 1 tahun 1974 tersebut merupakan aturan kongkrit dan relatif banyak melahirkan interpretasi dalam masyarakat. Terlepas dari hukum formal yang mengatur umur perkawinan, kawin muda merupakan fenomena yang terkait erat dengan nilai- nilai sosial, budaya, agama yang hidup dalam masyarakat.

Dalam konteks Indonesia, perkawinan lebih cenderung berupa kewajiban sosial dari manifestasi kehendak bebas setiap individu. Secara umum dapat dikemukakan hipotesis; bahwa dalam masyarakat yang pola hidup hubungannya bersifat tradisional, perkawinan dipersepsikan sebagai suatu "keharusan sosial" yang merupakan bahagian warisan tradisi dan dianggap sakral. Sedangkan dalam masyarakat modern, perkawinan lebih dianggap sebagai 'kontrak sosial', dan karenanya perkawinan lebih sering merupakan pilihan. Hal inilah cara pandang terhadap perkawinan muda yang terjadi di Indonesia (Syafiq, 1999: 132).

Ketentuan batas umur ini, seperti disebutkan dalam KHI didasarkan kepada pertimbangan kemaslahatan keluarga dan rumah tangga. Ini sejalan dengan prinsip yang diletakan UU Perkawinan, bahwa calon suami isteri harus telah masak jiwa raganya, agar dapat mewujudkan tujuan perkawinan secara baik tanpa berakhir pada perceraian dan mendapatkan keturunan yang baik dan sehat. Untuk itu harus dicegah adanya perkawinan antara calon suami isteri yang masih di bawah umur.

Masalah kematangan fisik dan jiwa seseorang dalam konsep Islam, tampaknya lebih ditonjolkan pada aspek yang pertama, yaitu fisik. Hal ini dapat dilihat misalnya dalam pembebanan hukum (taklif) bagi seseorang, yang dalam term teknis disebut mukallaf (dianggap mampu menanggung beban hukum).

Walaupun Undang-undang telah mengatur penentuan usia kawin, namun demikian karena sifatnya yang ijtihadi, 
ketentuan tersebut tidak bersifat kaku. Artinya, apabila karena sesuatu dan lain hal perkawinan dari mereka yang usianya di bawah 21 tahun-atau sekurangkurangnya 19 tahun untuk pria dan 16 tahun untuk wanita-Undang-undang tetap memberi jalan keluar dengan cara meminta dispensasi kepada pengadilan atau pejabat lain yang ditunjuk oleh kedua orang tua pihak pria maupun pihak wanita, sebagaimana diatur dalam pasal 7 ayat (2). (Pasal 7 ayat (2) menyebutkan, Dalam hal penyimpangan dalam ayat (1) pasal ini dapat minta dispensasi kepada Pengadilan atau pejabat lain yang diminta oleh kedua orang tua pihak pria atau pihak wanita. Lihat UU Perkawinan, 3) Selanjutnya, mekanisme memperoleh dispensasi tersebut diatur dalam pasal 6 (UU No. 1 Tahun 1974: 3).

Adanya konsesi bagi calon mempelai yang kurang dari sembilan belas tahun, atau enam belas tahun bagi wanita, dikarenakan adanya ayat al-Qur'an mengindikasikan kebolehan perkawinan sebelum mencapai usia baligh, sebagaimana bunyi ayat berikut:

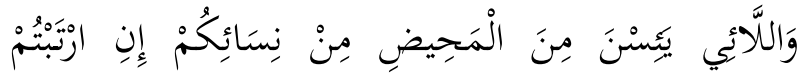

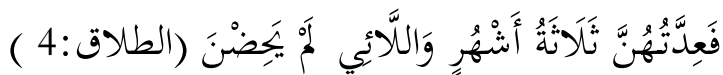

Dan perempuan-perempuan yang tidak haid lagi (monopause) di antara perempuanperempuanmu jika kamu ragu-ragu (tentang masa iddahnya), maka masa iddah mereka adalah tiga bulan; dan begitu (pula) perempuan-perempuan yang tidak haid... (Q.S. At-Thalaq [65]: 4).

Tataran aplikasi kebolehan tersebut harus dilampiri izin dari pejabat untuk itu. Ini menunjukkan bahwa penanaman konsep pembaharuan hukum Islam yang memang bersifat ijtihadi, diperlukan waktu dan usaha terus-menerus. Pendekatan konsep mashlahah mursalah dalam hukum Islam di Indonesia, memerlukan waktu agar masyarakat sebagai subyek hukum dapat menerimanya dan menjalankannya dengan suka rela tanpa ada unsur pemaksaan. Oleh karena itulah, pentingnya sosiologi hukum dalam upaya mengintrodusir pembaharuan hukum, mutlak diperlukan (Rofiq, 1998: 83).

KHI dan UU Perkawinan tersebut merupakan aturan kongkrit dan relatif banyak melahirkan interpretasi dalam masyarakat. Terlepas dari hukum formal yang mengatur umur perkawinan, kawin muda merupakan fenomena yang terkait erat dengan nilai-nilai sosial, budaya, agama yang hidup dalam masyarakat. Dalam konteks Indonesia perkawinan lebih cenderung berupa kewajiban sosial dari manifestasi kehendak bebas setiap individu. Secara umum dapat dikemukakan hipotesis; bahwa dalam masyarakat yang pola hidup hubungannya bersifat tradisional, perkawinan dipersepsikan sebagai suatu "keharusan sosial" yang merupakan bagian warisan tradisi dan dianggap sakral, sedangkan dalam masyarakat modern, perkawinan lebih dianggap sebagai "kontrak sosial", dan karenanya perkawinan lebih sering merupakan pilihan. Hal inilah cara pandang terhadap perkawinan muda yang terjadi di Indonesia (Syafiq, 1999: 132). Alasan yang dikemukakan karena faktor ekonomi, sosial buadaya atau gabungan keduanya adalah berangkat dari pemahaman bahwa mengawinkan anak perempuan sedini mungkin berarti akan meringankan beban ekonomi rumah tangga dan diasumsikan 
tidak lagi menjadi tanggung jawab orang tua).

UU Perkawinan No. 1 tahun 1974 ini, pernah digugat ke Mahkamah Konstitusi untuk judicial review oleh Dewan Pengurus Yayasan Kesehatan Perempuan Zumrotin. Mereka meminta untuk menaikkan batas usia minimal bagi perempuan menjadi 18 tahun. Alasannya, perkawinan anak dengan kehamilan dini di bawah usia 18 tahun beresiko tinggi. Si ibu masih dalam masa pertumbuhan sehingga terjadi perebutan gizi antara si ibu dengan janin. Pada 18 Juni 2015 Mahkamah Konstitusi menolak gugatan tersebut.

Dari paparan di atas, dapat diasumsikan bahwa penetapan batas usia calon pengantin dalam UU Perkawinan No. 1 tahun 1974, menggunakan metode ta'wil dalam ilmu ushul al-figh, meskipun tidak dijumpai pernyataan tegas tentang itu. Fakta literatur menunjukkan bahwa langkah-langkah yang ditempuh untuk menetapkan angka 19 bagi laki-laki dan 16 bagi perempuan sebagai pemalingan dari makna baligh yang boleh menikah dalam surat al-Maidah ayat 6, mempertimbangkan indikator nash (ayat dan hadits), 'urf, dan maqashid al-syari'ah.

Paparan tentang relevansi metode ta'wil terhadap kasus pembatasan usia perkawinan di atas, sepintas lalu terlihat seperti tafsir ayat dengan ayat atau dengan hadits yang dikelompokan pada tafsir bi al-ma'thur. Dugaan demikian, sepenuhnya tidaklah keliru, karena memang ulama salaf, pada awalnya menyamakan tafsir dengan ta'wil, القول في الق اختلف أهل التأويل في dan تأويل قوله تعالى كذ وكذ
هذه الأية. Kata ta'wil di sini adalah tafsir. Ulama belakanganlah (khalaf) yang mencoba membedakan antara ta'wil dengan tafsir (alQatan, t.th: 325).

Namun jika diamati secara seksama akan terlihat perbedaan antara tafsir dengan $t a^{\prime} w i l$ Menafsirkan, berarti menjelaskan maksud lafaz (بيان المعنى) yang diungkapkan secara zhahir, sedangkan ta'wil, menganjak arti zhahir suatu lafaz kepada makna lain berdasarkan dalil pendukung. Kata الدم dalam surat al-Maidah ayat 3, dita'wil dengan دما مسفوحا berdasarkan surat alAn'am ayat 145. Ta'wil semacam ini, membatasi (taqayyid) lafaz mutlaq dengan lafaz muqyyad. Ada juga ta'wil berupa takhshish, semisal keumuman lafaz المطلقات dalam surat al-Baqarah ayat 228 ditakhshish oleh surat al-Ahzab ayat 49 . Imam al-Syafi'i mena'wil ayat .الوجه والكفين dengan. .... لما ظهر منها...(النور:31) Ta'wil ini diperkuat oleh hadits tentang teguran Rasul SAW pada Asma' yang memakai pakaian tipis (Al-Zuhaili, 1986: 317). Dengan demikian, ta'wil membutuhkan tafsir untuk memindahkan makna rajih kepada makna marjuh.

Dengan demikian, metode $t a^{\prime}$ wil dinilai masih cocok dan relevan untuk diterapkan dalam pembaharuan hukum Islam di Indonesia. Hal ini dibuktikan setidaknya pada pada kasus hukum perkawinan (figh munakahat). Relevansi itu terlihat dalam menyelesaikan kasus tentang, pembatasan usia perkawinan. 


\section{KESIMPULAN}

1. Ta'wil menurut ushuliyyin yaitu, pemalingan suatu lafaz dari maknanya yang zhahir kepada makna lain yang tidak cepat ditangkap, karena ada dalil yang menunjukkan bahwa makna itulah yang dimaksud oleh lafaz tersebut. Lafaz yang bisa dita'wil adalah lafaz az-zahir. Ta'wil tidak berlaku pada nash-nash qath'i, muhkam dan mufassar. Sedangkan dalil ta'wil berupa nash (ayat atau hadith), qiyas (analogi), luhgawiyyah (kebahasaan), 'aqliyyah (logika), dan 'adad ('urf) yang berlaku pada masyarakat, dan dalil yang diperselisihkan (مختلف فيه) adalah hikmah al-tasyri' atau maqashid al-syari'ah yang hanya dipraktekkan oleh ulama ushul al-Hanafiyah. Medan ta'wil ulama ushuliyin ialah masalah-masalah furu' (nash-nash yang bersinggungan dengan hukum-hukum syari'ah). Dari pendalaman kajian tersebut, mereka menemukan beberapa bentuk ta'wil, diantaranya mengkhususkan lafaz yang umum (takhshish al-'am), membatasi lafaz yang mutlaq (taqyyid al-mutlaq), mengalihkan lafaz dari maknanya yang hakiki kepada yang majazi, atau dari maknanya yang mengandung wajib menjadi makna yang sunnah.

2. Metode $t a^{\prime} w i l$ dinilai masih cocok dan relevan untuk diterapkan dalam pembaharuan hukum Islam di Indonesia. Hal ini dibuktikan setidaknya pada kasus hukum perkawinan (figh munakahat). Relevansi itu terlihat dalam menyelesaikan kasus tentang, pembatasan usia perkawinan. Wallahu A'lam.

\section{DAFTAR KEPUSTAKAAN}

Abi Bakr bin 'Ali, Mahmud bin 'Abd arRahman bin Muhammad bin, Bayan al-Mukhtashar Syarh Mukhtashar alMuntaha al-Ibn al-Hajib fi Ushul alFigh, tt: Jami'ah Um al-Qura, t.th, jilid 2

Al- Amidi, 'Ali bin Muhammad, al-Ihkam fi Ushul Ahkam, ditahqiq oleh 'Abd al-Razaq 'Afifi, Riyad: Dar-al-Shami' $i$ Linasyr wa Tauzi', 2003, jilid 3

Al-Bannani, Hasyiyyah al-'Allahah alBannani 'ala Syarh al-Jalai Syams alDin Muhammad bin Ahmad al-Mahalli 'ala Matn Jam'i al-Jawami' li Imam Taj al-Din 'Abd al-Wahhab al-Subki, Bairut: Dar al-Fikr, 1982, jilid 2

Al-Ghazali, Abu Hamid, al-Mustashfa Min 'Ilm al-Ushul, Bairut: Dar al-Kutub al'Ilmiah, 2008, jilid 3

Al-Isfahani, al-Raghib, Mufradhah fi Gharib al-Qur'an, Maktabah Nizar Mustafa al-Baz, t.th, jilid 1

Al-Namlah, 'Abd al-Krim bin 'Ali bin Muhammad, al-Mahazzab fi 'Ilm Ushul al-Figh al-Muqaran, al-Riyadh: Makhtabah ar-Rasyid li al-Nasyir alTauzi', 1999, jilid 1

Al-Qurthubi, 'Abdullah Muhammad bin Ahmad al-Anshari, Tafsir al-Qurthbi, Bairut: Dar al-Kutub al-'Ilmiyyah, 2010, jilid 5

Al-Siba'i, Mustafa, al-Mar'ah bain al-Figh wa al-Qur'an, Damsyik: Maktabah alKitab, t.th

Al-Subki, 'Abd al-Wahhab bin Ali, Jam' alJawami' fi Ushul al-Figh, Bairut: Dar al-Kutub al-Ilmiah, 2003 
Al-Syafi'i, Muhammad bin Idris, arRisalah, ditahqiq oleh Ahmad Muhammad Syakir, Bairut: Maktabah al-Islamiyah, t.th, Cet ke-1

Al-Syathibi, Abu Ishaq, al-Muwafaqat, Khubar: Dar Ibn Affan, 1997, jilid 3

Al-Syawkani, Muhammad 'Ali, Irsyad alFuhul ila Tahqiq al-Haq min 'Ilm alUshul, Riyad: Dar al-Fadilah, 2000, jilid 2

Al-Zarkasyi, Muhammad bin 'Abdullah, al-Burhan fi Ulum al-Qur'an, Kairo: Dar al-Hadits, 2006

Al-Zuhaili, al-Figh al-Islami wa Adillatuh, Damsiq: Dar al-Fikr, 2008, jilid 1

- Wahbah, Ushul al-Figh al-Islami, Damsyiq: Dar al-Fikr, 1986, jilid 1

Djatmika, Rachmat, Sosialisasi Hukum Islam, dalam Abdurrahman Wahid, et.al, Kontroversi Pemikiran Islam di Indonesia, Bandung: Rosda Karya, 1991

Hasyim, Syafiq. ed, Menakar Harga Perempuan: Ekspolarasi Lanjut Atas Hak-hak Reproduksi Perempuan dalam Islam, Bandung: Mizan, 1999, Cet ke1

Ibn Faris, Mu'jam Maqayis al-Lughah, Bairut: Dar al-Fikr, 1979, jilid 1
Ibn Taimiyah, al-Iklil fi al-Mutasyabih wa alTa'wil, Iskandariyah: Dar al-Iman, t.th

Munawwir, Ahmad Warson, Kamus alMunawwir Arab Indonesia Terlengkap, Surabaya: Pustaka Progressif, 1997.

Rofiq, Ahmad, Hukum Islam di Indonesia, Jakarta: Raja Grafindo Persada, 1998, Cet ke-3

Syarifuddin, Amir, Hukum Perkawinan Islam di Indonesia Antara Figh Munakahat dan Undang-Undang Perkawinan, Jakarta: Kencana Prenada Media Group, 2009, Cet ke3

, Ushul Figh, Jakarta: Logos Wacana Ilmu, 1997, jilid 1, 2, Cet ke-1

Tawilah, 'Abd al-Wahab 'Abd al-Salam, Atsar al-Lughah fi Ikhtilaf alMujtahidin, t.t: Dar as-Salam Litaba'ah wa al-Nasyr wa al-Tauzi' wa al-Tarjamah, $1414 \mathrm{H}$

Zaidan, 'Abd al-Karim, al-Wajiz fi Ushul alFigh, Baghdad: Mu'assasah Qurtubah, 1976. 